\title{
PROPHETIC MINISTRY IN JEREMIAH AND EZEKIEL ${ }^{1}$
}

\author{
Kathleen M. Rochester
}

This study seeks to make a contribution to the understanding of Old Testament prophetic ministry by offering a close comparison of selected texts from two quite different, yet related, prophetic books: Jeremiah and Ezekiel. Both prophets focus on the fall of Jerusalem, and use many similar motifs in their messages. They portray overlapping historical contexts, yet their geographical settings are different. This mix of features in common with aspects that are quite dissimilar provides fertile ground for fruitful comparative study.

Even a cursory reading of these books reveals some striking differences: the book of Jeremiah has little obvious structure, is strongly word-orientated, and portrays a sensitive, emotional prophet who shows little interest in priestly matters but engages in lively dialogue with Yahweh. On the other hand, the book of Ezekiel is carefully structured, has a large amount of visionary material, and portrays a detached, self-disciplined prophet who is very influenced by priestly concerns and seems barely able to speak with Yahweh. In fact, the introductions to each book point to distinctive elements in each prophetic ministry and can well be taken as codes to how each book should be read: whereas the book of Jeremiah is introduced as 'the words of Jeremiah', the book of Ezekiel begins with 'and it happened' (ויהי), followed by visions of God.

Much of the scholarly work that specifically compares these two prophetic books focuses on compositional concerns, taking an approach which is not particularly useful for a comparative study of prophetic ministry. Some scholars take a psychological approach and postulate significant personality differences between the two prophets.

1 Kathleen M. Rochester, 'Prophetic Ministry in Jeremiah and Ezekiel' (Ph.D. dissertation, Durham University, 2009). Supervisor: Prof. R. Walter L. Moberly. 
This may be so, but our texts do not present us with personality profiles, so my study leaves questions of personality aside. Others go further with psychoanalytical approaches, particularly with the unusual figure of Ezekiel. However, the lack of agreement among such scholars only demonstrates the limitations of attempting psychoanalysis on someone who is of an ancient culture and whose textual material does not use a psychological framework. Furthermore, a diagnosis of pathology risks skewing the profundity of Ezekiel's message. Instead of psychological information, what we do have in these texts is a portrayal of events and aspects of context that the text considers important in relation to the ways in which these prophetic vocations unfold.

The striking difference in the primary mode of communication between these two prophetic books does receive some attention by scholars. Jeremiah's oracles are considered to be primarily oral, and only later written down, but Ezekiel's are taken as primarily written, even if sometimes presented orally. The visionary scroll-eating episode (Ezek. 2:9-3:3) is seen by some to support the view that Ezekiel marks a transition from orality to literacy. This also may be so, but a broader question needs to be asked, in accordance with the introductions, as to why Jeremiah is more word-orientated, and Ezekiel more visual and visionary. This question needs to be examined in the light of the contexts portrayed in each book.

In seeking to account for differences between these two prophets, I take a canonical approach, based on the received text, refraining from speculation concerning factors that lie outside the texts and, instead, giving serious consideration to the settings portrayed in each book. I propose that the differences in historical, geographical and, in particular, theological settings offer help in understanding some significant differences in these prophetic ministries, for each prophet comes to his relationship with Yahweh and his prophetic role from within the context of his people, and each must then act as a prophet to and for his specific people.

I proceed by making close exegetical comparisons of texts concerning the call of each prophet (Jer. 1 and Ezek. 1-3), the images that portray their prophetic work (assayer in Jer. 6:27-30, potter based on Yahweh's work in Jer. 18:1-12, and watchman in Ezek. 33:1-20), their relationship to the Jerusalem temple (Jer. 7:1-15 and Ezek. 8-11) and their specific criticisms of deviant prophets (Jer. 23:9-32 and Ezek. 
13). In each of these comparisons I also relate the differences in the portrayed settings to the specific differences in ministry as well as to the modes and styles of communication between Yahweh and prophet, and prophet and people.

There is much in common in these prophetic ministries. Both experience a remembered, personal encounter with Yahweh, in which they are addressed, commissioned and sent out to bear messages from Yahweh. Both speak of the need to turn away from wickedness in its various forms, and to conform humbly to Yahweh's requirements. Both must persevere in unpopular work, in the face of opposition which is, at times, strenuous. Both call for the person and presence of Yahweh to be regarded more highly than his temple and its cult. Both give warnings in relation to the fall of Jerusalem and its temple, and both speak out forcefully against prophets who have not been sent, whose messages are not from Yahweh, and whose lifestyles and motives are without integrity.

However, in Jeremiah, where his people are still in the land with the temple present, Yahweh is perceived as close, and the communication between Yahweh and prophet is characterised by intimate dialogue. Jeremiah's communication to the people is focused on Yahweh's spoken word, the medium of proximity. However, there appears to be a superficial over-familiarity with Yahweh without genuinely 'knowing' him, and Yahweh is not credited with any genuine 'knowing' of what is going on in the lives of the people and the nations. Complacency is rife and needs to be challenged by the prophet.

Where Ezekiel and his people have been forcibly removed from their land, they are very conscious of their distance from both temple and land; Yahweh is also presumed to be distant, because he dwells in Jerusalem. Communication between Yahweh and Ezekiel is more distant: sight can reach those who are too far away to hear. Ezekiel's style is often theatrical, putting him into the role of a spectator rather than that of a participant. His communication to the people is also more visual, more theatrical and also more distant. The divine hope is not that the people will 'know Yahweh' but 'know that' Yahweh has acted, or that a prophet has been in their midst. Yet, for those who assume that Yahweh has abandoned his exiles, surprising signs of Yahweh's proximity and hope are present.

Jeremiah's call for the people to 'turn' back to listen to Yahweh and obey suggests that a break in relationship has not fully developed; 
Ezekiel's call to respect the 'holiness' of Yahweh suggests that the relationship must begin again from a more distant point before drawing close to a place of intimacy.

The particular shape of each prophetic ministry is significantly influenced by the particular context-historical, geographical, and particularly theological - in which each prophet operates. 